\title{
Uptake of Polycyclic Aromatic Hydrocarbons across Bacterial Membrane
}

\author{
Shaomin Yan, Guang $\mathrm{Wu}^{*}$ \\ State Key Laboratory of Non-Food Biomass and Enzyme Technology, National Engineering Research Center for Non-Food \\ Biorefinery, Guangxi Key Laboratory of Biorefinery, Guangxi Academy of Sciences, Nanning, China \\ Email: *hongguanglishibahao@gxas.cn
}

How to cite this paper: Yan, S.M. and $\mathrm{Wu}$, G. (2020) Uptake of Polycyclic Aromatic Hydrocarbons across Bacterial Membrane. Advances in Microbiology, 10, 331-348. https://doi.org/10.4236/aim.2020.107024

Received: June 4, 2020

Accepted: July 19, 2020

Published: July 22, 2020

Copyright (c) 2020 by author(s) and Scientific Research Publishing Inc. This work is licensed under the Creative Commons Attribution International License (CC BY 4.0).

http://creativecommons.org/licenses/by/4.0/ (c) (i) Open Access

\begin{abstract}
Polycyclic aromatic hydrocarbons (PAHs) are important pollutants, whose biodegradation and bioremediation with microorganisms are the promising ways to clean environments and reduce their exposure to humans. Although the transportation of PAHs across bacterial membrane is the first step forwards their biodegradation, it receives less attention. In this mini-review, we explore which transport system for uptake of carbon sources can serve for uptake of PAHs in bacteria, and try to uncover some patterns in their transport mechanisms. Collectively, 1) the major carbohydrate transport system, PTS, is unlikely to take PAHs because PAHs lack a hydroxy group for phosphorylation but aromatic acids are good candidates; 2) PAHs could probably go through $\mathrm{H}^{+}$ symporters, especially the low-molecular-weight PAHs, which are partially dissolvable in water; 3 ) it is unlikely that PAHs can produce chemiosmotic ion gradients to go through uniporters; and 4) antiporters could serve as transporters to transport PAHs across bacterial membrane only after the metabolism of PAHs generates extra $\mathrm{H}^{+}$inside cell. Accordingly, the basic mechanism for uptake of PAHs is whether they can donate $\mathrm{H}^{+}$in order to generate an electrochemical proton gradient to go through symporters.
\end{abstract}

\section{Keywords}

Bacteria, Polycyclic Aromatic Hydrocarbon, Transport Mechanisms

\section{Introduction}

Polycyclic aromatic hydrocarbons (PAHs) are important pollutants coming from crude oil, creosote, asphalt, coal tar, combustion of fossil fuels, burning of sugarcane, etc. [1]. Their existence is harmful not only to humans but also to environments [2]. Microbial degradation is a promising way for recovery of envi- 
ronment from PAH contamination [3] [4]. It turns out that some bacteria use PAHs as their sole carbon source to survive (Table 1).

Utilization of PAHs is possible because the benzene ring is one of the most abundant chemical structures in the biosphere, its derivatives are accessible to microorganisms as their growth substrates [22] and PAHs are largely natural products [23]. However, an important difference between PAHs and non-PAHs carbon sources is that most PAHs are generally hydrophobic although 2-ring and several 3-ring PAHs are dissolvable in water to some degree [24]. Of various factors, the size and angularity of PAH contribute to its hydrophobicity and electrochemical stability [25]. Glucose is highly soluble in water, by contrast, PAHs reveal low aqueous solubility; however, they are easily absorbed to solid particles in soil [26]. Because bacteria usually take degraded solvable chemicals [24], an interesting question is how PAHs are transported across bacterial membrane. Indeed, bacteria can secrete surfactants [27] [28], for example, $P$. aeruginosa can secrete rhamnolipid to facilitate the uptake of hydrophobic substrates [29] [30]. Can a bacterium evolve a specific transporter to transport PAHs from environment into cells? It could be possible, because a bacterium may encounter a few types of PAHs during its lifetime. On the other hand, it is hard to imagine that a bacterium would evolve many specific transporters for each type of PAHs because at least $660 \mathrm{PAH}$ structures have so far been defined [31]. Therefore, it is highly likely that bacteria would use their non-specific transport systems to move PAHs into cells rather than to evolve specific transporters for each $\mathrm{PAH}$.

Although the catabolism of PAHs in bacteria has been intensively studied and reviewed, the transportation of PAHs across bacterial membrane has yet to receive great attention. In broader sense, PAHs are aromatic compounds including aromatic acids so that the uptake of aromatic compounds should draw more attention.

Table 1. Some PAH compounds as sole carbon source for survival of bacteria.

\begin{tabular}{ccc}
\hline PAH & Bacterium & References \\
\hline anthracene & Pseudomonas fluorescens 5R & {$[5][6]$} \\
naphthalene & Comamonas testosteroni GZ42 & {$[7][8]$} \\
naphthalene & Rhodococcus sp. NCIMB 12038, P200, P400 & {$[9][10][11]$} \\
fluoranthene & P.paucimobilis EPA505 (now Sphingomonas paucimobilis EPA505) & {$[12][13]$} \\
fluoranthene & Mycobacterium vanbaalenii PYR-1 & {$[14]$} \\
phenanthrene & Alcaligenes faecalis AFK2 & {$[15][16]$} \\
phenanthrene & Arthrobacter sp. P1-1 & {$[17]$} \\
phenanthrene & Burkholderia sp. C3 & {$[18]$} \\
phenanthrene & Comamonas testosteroni & {$[7][19]$} \\
phenanthrene & P. fluorescens & {$[5][20]$} \\
pyrene & M. vanbaalenii PYR-1 & {$[21]$} \\
\hline
\end{tabular}


As bacteria can use aromatic compounds as carbon sources, the system for uptake of carbon sources in bacteria should be considered in the first place. The first system for uptake of carbons is the phosphoenolpyruvate (PEP):carbohydrate phosphotransferase system (PTS), which is an active transporter consuming ATP. The second system is highly likely to be symporters, which are the secondary active transporters without consuming ATP.

In fact, many bacteria transfer aromatic acids into cells using major facilitator superfamily (MFS), of which the aromatic acid: $\mathrm{H}^{+}$symporter is the most important one. The other MFS members, which are involved in transporting aromatic compounds, include: 1) BenK, which transfers benzaldehyde [32] [33] and benzoate (from which comes BenK), 2) GenK, which transfers 3-hydroxybenzoate and 2,5-dihydroxybenzoate (gentisate, from which comes GenK) [34], 3) MhbT, which transfers 3-hydroxybenzoate [35], and 4) PcaK, which transfers 4-hydroxybenzoate and 3,4-dihydroxybenzoate (protocatechuate, from which comes PcaK) [36] [37].

Besides MFS, aromatic compounds can be transported through several different transporters. For instance, phthalate is transported into Burkholderia cepacia through three pathways, 1) OphD [38], 2) OphFGH, which is an ATP-binding cassette (ABC) [39], and 3) OphP [39].

So far, it is not very clear whether there are other transporters involved in the uptake of carbon sources. In this mini-review, we explore through which transporters PAHs are transported across bacterial membrane.

\section{Can PAHs Pass through PTS?}

PTS is the major carbohydrate transport system in bacteria (upper part, Figure 1 ), which is usually composed of enzyme E I (EI), histidine protein (HPr,

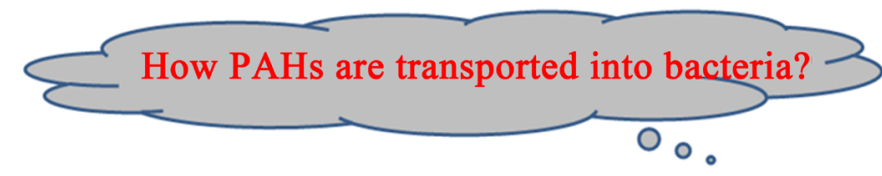

\section{PTS Phosohoenolpyruvate-dependent} sugar phosphotransferase system

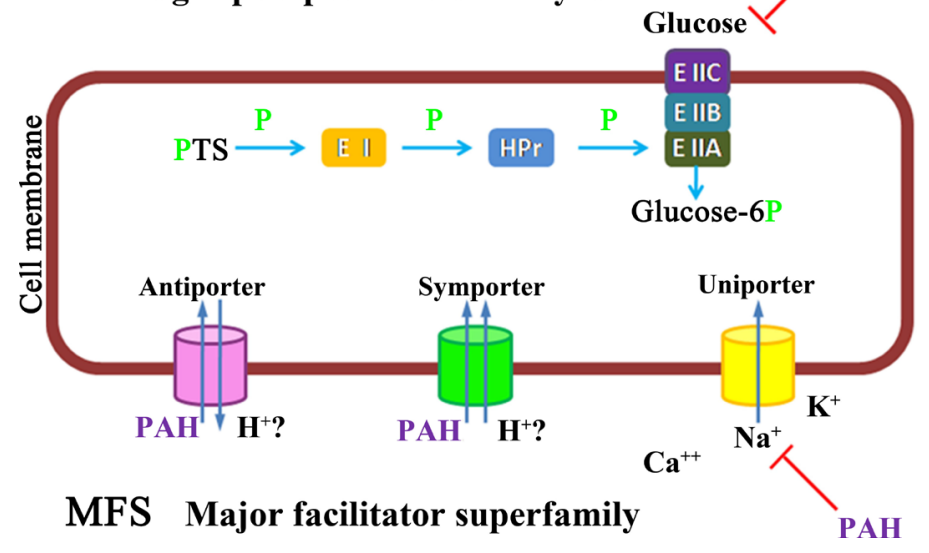

Figure 1. Possible transporters for uptake of PAHs in bacteria. 
heat-stable protein) and enzyme E II (EII) [40] [41]. PTS only exists in bacteria, which was initially found in Escherichia coli [42] and then was found in other bacteria [41]. Although E. coli does not play an important role in PAH degradation, the knowledge on PTS of E. coli is useful for our understanding on whether PAHs can pass through PTS.

So far, PTS has been classified into four superfamilies according to their EII's phylogeny [43]: 1) the glucose-fructose-lactose superfamily including glucose, fructose-mannitol and lactose families, 2) the ascorbate-galactitol superfamily including ascorbate [44] [45] and galactitol families [46] [47], 3) the mannose family [48], and 4) the dihydroxyacetone family [49]. Taking glucose as an example, the main mechanism for such transportation across the cell membrane is to phosphorylate glucose into glucose-6-phosphate using enzyme II B (EIIB) with consumption of ATP when glucose crosses plasma membrane through the trans-membrane enzyme II C (EIIC). Thus, the transport of glucose is an active process.

The PTS substrates include monosaccharides (glucose, fructose and mannose), disaccharides (cellobiose), amino sugars (glucosamine, $\mathrm{N}$-acetylglucosamine and $\mathrm{N}$-acetylmannosamine), as well as polyols [41] [42]. Clearly, this list does not include any PAHs, so a question is whether PAHs can be transported into bacteria through PTS.

The size of PTS substrates varies largely. For monosaccharides, glucose has long and short axes of $8.6 \AA$ and $8.4 \AA$ [50], and fructose has long and short axes of $9.8 \AA$ and $8.5 \AA$ [50]. For polyols, mannitol has a size of $11.92 \AA \times 8.11 \AA \times$ $7.38 \AA$ [51].

For PAHs, they are usually grouped as low-molecular-weight PAHs with 2 to 4 benzene rings (naphthalene, phenanthrene, anthracene and fluorene) and high-molecular-weight PAHs with more than 4 benzene rings (fluoranthene, benzo $[\alpha]$ pyrene, benz $[\alpha]$ anthracene and 7,12-dimethylbenz $[\alpha]$ anthracene) [52]. The size of five typical PAHs is listed in Table 2. As can be seen, the sizes of 2-ring naphthalene and 3-ring anthracene and phenanthrene are compatible with the size of mannitol, so PTS could at least accommodate a portion of low-molecular-weight PAHs in terms of their size.

In addition to PAH size, another necessary prerequisite for PTS transportation is whether PAHs can be phosphorylated because phosphorylation is the first

Table 2. Size of $5 \mathrm{PAH}$ compounds [31].

\begin{tabular}{ccc}
\hline PAH & Long axis & Short axis \\
\hline 2-ring naphthalene & $9.195 \AA$ & $7.428 \AA$ \\
3-ring anthracene & $11.650 \AA$ & $7.439 \AA$ \\
3-ring phenanthrene & $11.750 \AA$ & $8.031 \AA$ \\
4-ring fluoranthene & $11.160 \AA$ & $9.240 \AA$ \\
4-ring pyrene & $11.660 \AA$ & $9.279 \AA$ \\
\hline
\end{tabular}


step to transport glucose across membrane. To achieve this, PAHs need to have a hydroxy group on any of its carbons for phosphorylation. This prerequisite, however, needs to add oxygen to PAHs as a necessary step before phosphorylation because PAHs have no oxygen. Take naphthalene as an example for this possibility (Figure 2), naphthalene needs an oxygen to form a hydroxy group, and then it can go through phosphorylation with consumption of ATP, and then finally it can go through PTS into bacteria. However, the addition of oxygen requires oxygenase, which could break the aromatic ring as the ring-cleaving dioxygenases do [53], so PAHs are unlikely to be transported by PTS. On the other hand, the inhibition of surfactant, Triton X-100, on the metabolism of fluoranthene and glucose in Sphingomonas paucimobilis strain EPA505 [54] might suggest the possibility that the transporters for fluoranthene and glucose share some similarity.

Aromatic acids, such as benzoate and phenylacetic acid, appear to be possible candidates for PTS because they have a hydroxy group (Figure 3), which can be

\section{Hydroxylation}<smiles>CC1C=CC=CC=CC1</smiles>

Naphthalene<smiles>Oc1cccc2ccccc12</smiles>

1-Naphthol

\section{Phosphorylation

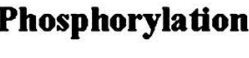

Figure 2. Possible mechanism for PAHs to be transported by PTS with naphthalene as an example.<smiles>O=C(O)c1ccccc1</smiles>

\section{Benzoate}<smiles>O=C(O)Cc1ccccc1</smiles>

Phenylacetic acid

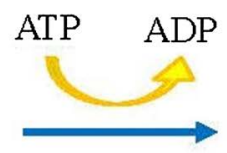

Phosphorylation

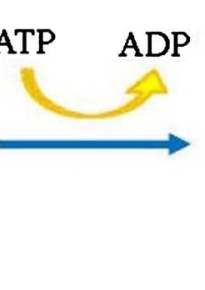

Naphthalene-1-phosphate<smiles>O=P(O)(O)Oc1cccc2ccccc12</smiles>

Figure 3. Possible mechanism for benzoate and phenylacetic acid with their hydroxy group to be transported by PTS. 
used for phosphorylation. This can explain why benzoate and phenylacetic acid can be utilized in Pseudomonas prior to glucose as organic acids [55]. In reality, benzoate and phenylacetic acid are transported through aromatic acid: $\mathrm{H}^{+}$ symporter [56], but if they could be phosphorylated, they would block the uptake of glucose through PTS, then the preference order of utilization of carbon sources would be different in Pseudomonas.

\section{Can PAHs Pass through MFS?}

MFS (lower part, Figure 1) is the largest family of secondary active membrane transporters [57], and transports the non-PTS substrates because these substrates are not subject to phosphorylation. About $25 \%$ of all known membrane transport proteins belong to MFS in prokaryotes [58].

MFS has three types of transporters: 1) uniporter, which transports the substrates whose concentration gradient push power transportation; 2) symporter, which simultaneously transports two or more substrates in the same direction because of the electrochemical gradient of one of its substrates; and 3) antiporter, which transports two or more substrates in opposite directions. MFS can transport ions, simple sugars [59] [60], sugar phosphates, oligosaccharides, inositols, drugs [61], neurotransmitters, nucleosides, amino acids and peptides, organophosphate esters, Krebs cycle metabolites, lipids, and a large variety of organic and inorganic anions and cations [57] [62].

\section{Uniporter}

Can PAHs go through uniporter (right-lower corner of Figure 1) along the concentration gradient across the membrane? In plain words, can PAHs diffuse through plasma membrane? It seems unlikely because uniporters appear to be merely involved in transport of calcium, sodium and potassium [60] [63], although PAHs should generate a PAH concentration gradient across the bacterial membrane. The key point is that PAHs are not able to produce chemiosmotic ion gradients.

\section{Symporter}

Can PAHs go through symporters (middle lower part of Figure 1)? Aromatic acids could produce electrochemical gradients, and thus go readily through symporters. Aromatic acid: $\mathrm{H}^{+}$symporter (AAHS) family (TC\# 2.A.1.15) is the best studied symporter in terms of transportation of aromatic acids. AAHS family includes at least BenK, GenK, MhbT, MucK [64], PcaK and VanK for transportation of aromatic acids. After passing through BenK, MucK, PcaK and VanK, aromatic acids undergo mineralization via $\beta$-ketoadipate pathway [65] [66].

As aromatic acids can pass through symporters, can PAHs pass through aromatic AAHS family? Essentially, the substrates for AAHS family are 1-ring aromatic acids, i.e., 3-hydroxybenzoate, 4-hydroxybenzoate, 2,4-dihydroxybenzoate, 2,5-dihydroxybenzoate (gentisate), 3,4-dihydroxybenzoate (protocatechuate), 4-hydroxy-3-methoxybenzoate (vanillate), benzaldehyde, benzoic acid, and sa- 
licylate. Evidently, the size of 1-ring aromatic acids is smaller than any typical PAHs.

In eukaryotic organisms, the pathogenic yeast Candida parapsilosis has permeases $\mathrm{Hbt1}$ and $\mathrm{Hbt2}$, which are similar to bacterial aromatic acid: $\mathrm{H}^{+}$ symporters (AAHS) such as GenK, MhbT and PcaK. Permeases Hbt1 and Hbt2 transport 3-hydroxybenzoate, 4-hydroxybenzoate and protocatechuate into $C$. parapsilosis [67], and then are metabolized through different pathways. For example, 3-hydroxybenzoate and 2,5-dihydroxybenzoate are metabolized via the gentisate pathway, while hydroquinone, resorcinol, 4-hydroxybenzoate, 2,4dihydroxybenzoate ( $\beta$-resorcylate) and 3,4-dihydroxybenzoate (protocatechuate) are metabolized via 3-oxoadipate pathway [68] [69] [70].

In general, the mechanism for transportation of aromatic acids is simplified as [56]: benzoate (out) $+\mathrm{H}^{+}$(out) $\rightarrow$ benzoate (in) $+\mathrm{H}^{+}$(in).

For more complicated mechanism, it would be functionally asymmetric in PcaK [71], where an electrochemical proton gradient $\left(\Delta \mu^{-} \mathrm{H}^{+}\right)$or a membrane potential $(\Delta \Psi)$, but not $\Delta \mathrm{pH}$ alone, energizes asymmetric transportation [37]. This is why the number of substrates for AAHS is relatively small [37]. The implication is that PAHs should donate $\mathrm{H}^{+}$in order to generate an electrochemical proton gradient across the aromatic acid: $\mathrm{H}^{+}$symporters (AAHS), which is possible for low-molecular-weight PAHs because they are dissolvable in water to some extend [24]. So it is likely that naphthalene, for example, can go through AAHS in such a way (Figure 4).

Anion:cation symporter (ACS) family (TC\# 2.A.1.14) includes OphD and OphP in B. cepacia [39], and Pht1 in Pseudomonas putida [72] for transporting phthalate. Actually, the size of phthalate can be very large and comparable with even high-molecular-weight PAHs, because phthalate can be as simple as phthalic acid but complicated with different functional groups (Figure 5). Therefore, there is a possibility that PAHs generate anion and cation to go through anion:cation symporter.

Similarly, the rest $\mathrm{H}^{+}$symporters follow the same reasoning for uptake of PAHs. Metabolite: $\mathrm{H}^{+}$symporter (MHS) family (TC\# 2.A.1.6) includes MopB in B. cepacia for transporting 4-methyl-o-phthalate [73], PcaT in $P$ putida for transporting beta-ketoadipate [74] and ferulic acid [75], and ShiA in E. coli for transporting shikimate [76].

Oligosaccharide: $\mathrm{H}^{+}$symporter (OHS) family 2 (TC\# 2.A.1.5) includes lactose: $\mathrm{H}^{+}$permease (LacY) [57] from Citrobacter freundii, Klebsiella pneumoniae<smiles>c1ccc2ccccc2c1</smiles>

Naphthalene<smiles></smiles>

Ionized naphthalene

Figure 4. Possible mechanism for naphthalene to go through aromatic acid: $\mathrm{H}^{+}$symporters. 
<smiles>O=C(O)c1ccccc1</smiles>

Phthalic acid<smiles>[R]OC(=O)c1ccccc1</smiles>

Phthalate<smiles>O=C(O[OH2+])c1ccccc1</smiles>

Ionized phthalic acid<smiles>[R]OC(=O)c1ccccc1</smiles>

Ionized phthalate

Figure 5. Possible mechanism for phthalic acid and phthalate to go through aromatic acid: $\mathrm{H}^{+}$symporters.

and E. coli [77] [78] [79] [80] [81]; sucrose permease (CscB) from E. coli [82] [83] [84]; melibiose permease (MelY) from Enterobacter cloacae [85] and melibiose permease MelB from E. coli [86] [87] [88] and Salmonella typhimurium [89]. This family transports galactosides such as lactose and melibiose [90] [91] [92] with electrochemical proton gradient. OHS family seems to be a very good candidate for transporting PAHs, because the LacY is a $6 \mathrm{~nm} \times 3 \mathrm{~nm}$ oval shaped transporter on membrane surface [93].

It was found that the amino acid-polyamine-organocation (APC) transporter such as BenE [94] and the outer membrane pore-forming protein (OMPP) such as BenP [33] transport aromatic substrates.

In other kingdoms, studies on basidiomycete Trichosporon cutaneum found an energy-dependent system for the uptake of phenol, where phenolate anions are co-transported with protons in stoichiometry 1:1 [95] [96]. In another basidiomycete Fomitopsis palustris, symporter with $\mathrm{H}^{+}$ion was shown for the uptake of vanillate [97]. In humans, sodium-coupled monocarboxylate transporters, i.e. SMCT1 and SLC5A8, are involved in the uptake of nicotinate and various aromatic monocarboxylates such as benzoate and salicylate [98].

For the non-PTS sugars, the uptake of raffinose [99] across the cytoplasmic membrane of $E$. coli is a secondary active transporter termed as the raffinose permease (RafB) [99] [100] [101] [102]. Interestingly, galactose belongs to monosaccharide but it does not pass PTS system. The uptake system for galactose [103], galactose permease or GalP, belongs to MFS [104] [105] [106] [107]. No information is found that these two transporters could transport PHAs across bacterial membrane.

In this context, symporters could potentially serve as a biosensor system [108] to detect the PAH influx as mitochondria as biosensors of calcium microdomains [109] or special antibody could be used for this purpose [110]. Clearly, more experimental evidence is in need to explore this aspect of symporters with PAH up- 
take.

\section{Antiporter}

Can PAHs go through antiporters (left-lower corner of Figure 1)? This looks unlikely because there is usually no $\mathrm{H}^{+}$inside bacteria. However, the common catabolic pathway to salicylate from naphthalene [111], fluorine [112] and phenanthrene [18] can generate extra $\mathrm{H}^{+}$. Still, the common catabolic pathway to phthalate from fluorine [113], anthracene [114], phenanthrene [18], and pyrene [21] can generate extra $\mathrm{H}^{+}$. Thus the produced $\mathrm{H}^{+}$could be used for antiporter to transport PAHs; however this process could begin only after the beginning of metabolism of PAHs, so the uptake of PAHs through antiporter can occur at a later stage.

\section{Conclusions}

In this mini-review, every effort was made to find how PAHs are transported into bacterial cells in literature. Because of lack of recent research in this field, our review focuses on the theoretical derivation in order to stimulate the research interests. In a broader sense, this is the question of how hydrophobic substances are transported into bacteria and which transporter is used to transport less soluble substances. Although the substrate-dependent gene modulation can inhibit the glucose transport and metabolism [115], which would create the conditions for transporting PAHs and their utilization. Collectively, 1) the major carbohydrate transport system, PTS, is unlikely to take PAHs because PAHs lack a hydroxy group for phosphorylation but aromatic acids are good candidates; 2) PAHs could probably go through $\mathrm{H}^{+}$symporters, especially the low-molecular-weight PAHs which are partially dissolvable in water; 3) it is unlikely that PAHs can produce chemiosmotic ion gradients to go through uniporters; and 4) antiporters could serve as transporters to transport PAHs across bacterial membrane only after the metabolism of PAHs generates extra $\mathrm{H}^{+}$inside cell. Accordingly, the basic mechanism for uptake of PAHs is whether they can donate $\mathrm{H}^{+}$in order to generate an electrochemical proton gradient to go through symporters. However, it is still not clear how the high-molecular-weight PAHs are transported into cells. Thus, more studies are needed in order to understand how PAHs are transported into bacteria. The current literature has yet to provide sufficient knowledge on uptake dynamics if we consider the driving force in transportation as uptake kinetics. Therefore, the uptake dynamics should be a direction for pursuit.

\section{Funding}

This study was partly supported by National Natural Science Foundation of China (No. 31460296 and 31560315), Key Project of Guangxi Scientific Research and Technology Development Plan (AB17190534).

\section{Conflicts of Interest}

The authors declare no conflicts of interest regarding the publication of this paper. 


\section{References}

[1] Ferreira, L.E., Muniz, B.V., Bittar. T.O., Berto, L.A., Figueroba, S.R., Groppo, F.C. and Pereira, A.C. (2014) Effect of Particles of Ashes Produced from Sugarcane Burning on the Respiratory System of Rats. Environmental Research, 135, 304-310. https://doi.org/10.1016/j.envres.2014.07.030

[2] Cao, B., Nagarajan, K. and Loh, K.-C. (2009) Biodegradation of Aromatic Compounds: Current Status and Opportunities for Biomolecular Approaches. Applied Microbiology and Biotechnology, 85, 207-228.

https://doi.org/10.1007/s00253-009-2192-4

[3] Peng, R.-H., Xiong, A.-S., Xue, Y., Fu, X.-Y., Gao, F., Zhao, W., Tian, Y.-S. and Yao, Q.-H. (2008) Microbial Biodegradation of Polyaromatic Hydrocarbons. FEMS Microbiology Reviews, 32, 927-955. https://doi.org/10.1111/j.1574-6976.2008.00127.x

[4] Bisht, S., Pandey, P., Bhargava, B., Sharma, S., Kumar, V. and Sharma, K.D. (2015) Bioremediation of Polyaromatic Hydrocarbons (PAHs) Using Rhizosphere Technology. Brazilian Journal of Microbiology, 46, 7-21. https://doi.org/10.1590/S1517-838246120131354

[5] Menn, F.M., Applegate, B.M. and Sayler, G.S. (1993) NAH Plasmid-Mediated Catabolism of Anthracene and Phenanthrenen to Naphthoic Acids. Applied and Environmental Microbiology, 59, 1938-1942. https://doi.org/10.1128/AEM.59.6.1938-1942.1993

[6] Leblond, J.D., Schultz, T.W. and Sayler, G.S. (2001) Observations on the Preferential Biodegradation of Selected Components of Polyaromatic Hydrocarbon Mixtures. Chemosphere, 42, 333-343. https://doi.org/10.1016/S0045-6535(00)00161-2

[7] Goyal, A.K. and Zylstra, G.J. (1997) Genetics of Naphthalene and Phenanthrene Degradation by Comamonas testosteroni. Journal of Industrial Microbiology \& Biotechnology, 19, 401-440. https://doi.org/10.1038/sj.jim.2900476

[8] Daane, L.L., Harjono, I., Zylstra, G.J. and Häggblom, M.M. (2001) Isolation and Characterization of Polycyclic Aromatic Hydrocarbon-Degrading Bacteria Associated with the Rhizosphere of Salt Marsh Plants. Applied and Environmental Microbiology, 67, 2683-2691. https://doi.org/10.1128/AEM.67.6.2683-2691.2001

[9] Kulakov, L.A., Allen, C.C.R., Lipscomb, D.A. and Larkin, M.J. (2000) Cloning and Characterization of a Novel cis-Naphthalene Dihydrodiol Dehydrogenase Gene (narB) from Rhodococcus sp. NCIMB 12038. FEMS Microbiology Letters, 182, 327-331. https://doi.org/10.1111/j.1574-6968.2000.tb08916.x

[10] Kulakov, L.A., Chen, S.C., Allen, C.C.R. and Larkin, M.J. (2005) Web-Type Evolution of Rhodococcus Gene Clusters Associated with Utilization of Naphthalene. Applied and Environmental Microbiology, 71, 1754-1764. https://doi.org/10.1128/AEM.71.4.1754-1764.2005

[11] Dandare, S.U., Skvortsov, T., Arkhipova, K. and Allen, C.C.R. (2018) Draft Genome Sequence of Rhodococcus sp. Strain NCIMB 12038, a Naphthalene-Degrading Bacterium. Genome Announcements, 6, e01420-e01417. https://doi.org/10.1128/genomeA.01420-17

[12] Mueller, J.G., Chapman, P.J., Blattmann, B.O. and Pritchard, P.H. (1990) Isolation and Characterization of a Fluoranthene-Utilizing Strain of Pseudomonas paucimobilis. Applied and Environmental Microbiology, 56, 1079-1086. https://doi.org/10.1128/AEM.56.4.1079-1086.1990

[13] Story, S.P., Kline, E.L., Hughes, T.A., Riley, M.B. and Hayasaka, S.S. (2004) Degradation of Aromatic Hydrocarbons by Sphingomonas paucimobilis Strain EPA505. Archives of Environmental Contamination and Toxicology, 47, 168-176. 
https://doi.org/10.1007/s00244-004-3069-2

[14] Kweon, O., Kim, S.J., Jones, R.C., Freeman, J.P., Adjei, M.D., Edmondson, R.D. and Cerniglia, C.E. (2007) A Polyomic Approach to Elucidate the Fluoranthene-Degradative Pathway in Mycobacterium vanbaalenii PYR-1. Journal of Bacteriology, 189, 4635-4647. https://doi.org/10.1128/JB.00128-07

[15] Kiyohara, H., Nagao, K., Kouno, K. and Yano, K. (1982) Phenanthrene-Degrading Phenotype of Alcaligenes faecalis AFK2. Applied and Environmental Microbiology, 43, 458-461. https://doi.org/10.1128/AEM.43.2.458-461.1982

[16] Lozada, M., Riva Mercadal, J.P., Guerrero, L.D., Di Marzio, W.D., Ferrero, M.A. and Dionisi, H.M. (2008) Novel Aromatic Ring-Hydroxylating Dioxygenase Genes from Coastal Marine Sediments of Patagonia. BMC Microbiology, 8, Article No. 50. https://doi.org/10.1186/1471-2180-8-50

[17] Seo, J.-S., Keum, Y.-S., Hu, Y.T., Lee, S.E. and Li, Q.X. (2006) Phenanthrene Degradation in Arthrobacter sp. P1-1: Initial 1,2-, 3,4- and 9,10-Dioxygenation, and $\mathrm{Me}$ ta- and Ortho-Cleavages of Naphthalene-1,2-Diol after Its Formation from Naphthalene-1,2-Dicarboxylic Acid and Hydroxyl Naphthoic Acids. Chemosphere, 65, 2388-2394. https://doi.org/10.1016/j.chemosphere.2006.04.067

[18] Seo, J., Keum, Y., Hu, Y., Lee, S. and Li, Q.X. (2006) Degradation of Phenanthrene by Burkholderia sp. C3: Initial 1,2- and 3,4-Dioxygenation and Meta- and Ortho-Cleavage of Naphthalene-1,2-Diol. Biodegradation, 18, 123-131. https://doi.org/10.1007/s10532-006-9048-8

[19] Azwani, F., Suzuki, K., Honjyo, M., Tashiro, Y. and Futamata, H. (2017) Draft Genome Sequence of Comamonas testosteroni R2, Consisting of Aromatic Compound Degradation Genes for Phenol Hydroxylase. Genome Announcements, 5, e00875-e00817. https://doi.org/10.1016/j.chemosphere.2006.04.067

[20] Adebusuyi, A.A., Smith, A.Y., Gray, M.R. and Foght, J.M. (2012) The EmhABC Efflux Pump Decreases the Efficiency of Phenanthrene Biodegradation by Pseudomonas fluorescens Strain LP6a. Applied Microbiology and Biotechnology, 95, 757-766. https://doi.org/10.1007/s00253-012-3932-4

[21] Kim, S.J., Kweon, O., Jones, R.C., Freeman, J.P., Edmondson, R.D. and Cerniglia, C.E. (2007) Complete and Integrated Pyrene Degradation Pathway in Mycobacterium vanbaalenii PYR-1 Based on Systems Biology. Journal of Bacteriology, 189, 464-472. https://doi.org/10.1128/JB.01310-06

[22] Fuchs, G., Boll, M. and Heider, J. (2011) Microbial Degradation of Aromatic Compounds-From One Strategy to Four. Nature. Reviews Microbiology, 9, 803-816. https://doi.org/10.1038/nrmicro2652

[23] Ravindra, K., Sokhi, R. and Van Grieken, R. (2008) Atmospheric Polycyclic Aromatic Hydrocarbons: Source Attribution, Emission Factors and Regulation. Atmospheric Environment, 42, 2895-2921. https://doi.org/10.1016/j.atmosenv.2007.12.010

[24] Johnsen, A.R., Wick, L.Y. and Harms, H. (2005) Principles of Microbial PAH-Degradation in Soil. Environmental Pollution, 133, 71-84. https://doi.org/10.1016/j.envpol.2004.04.015

[25] Kanaly, R.A. and Harayama, S. (2000) Biodegradation of High-Molecular-Weight Polycyclic Aromatic Hydrocarbons by Bacteria. Journal of Bacteriology, 182, 2059-2067. https://doi.org/10.1128/JB.182.8.2059-2067.2000

[26] Zhang, J., Fan, S.K., Du, X.M., Yang, J.C., Wang, W.Y. and Hou, H. (2015) Accumulation, Allocation, and Risk Assessment of Polycyclic Aromatic Hydrocarbons (PAHs) in Soil-Brassica chinensis System. PLoS ONE, 10, e0115863. 
https://doi.org/10.1371/journal.pone.0115863

[27] Decesaro, A., Machado, T.S., Cappellaro, Â.C., Reinehr, C.O., Thomé, A. and Colla, L.M. (2017) Biosurfactants During in Situ Bioremediation: Factors That Influence the Production and Challenges in Evolution. Environmental Science and Pollution Research, 24, 20831-20843. https://doi.org/10.1007/s11356-017-9778-7

[28] Hajfarajollah, H., Eslami, P., Mokhtarani, B. and Akbari Noghabi, K. (2018) Biosurfactants from Probiotic Bacteria: A Review. Biotechnology and Applied Biochemistry, 65, 768-783. https://doi.org/10.1002/bab.1686

[29] Noordman, W.H. and Janssen, D.B. (2002) Rhamnolipid Stimulates Uptake of Hydrophobic Compounds by Pseudomonas aeruginosa. Applied and Environmental Microbiology, 68, 4502-4508. https://doi.org/10.1128/AEM.68.9.4502-4508.2002

[30] Ma, Z., Liu, J., Dick, R.P., Li, H., Shen, D., Gao, Y., Waigi, M.G. and Ling, W. (2018) Rhamnolipid Influences Biosorption and Biodegradation of Phenanthrene by Phenanthrene-Degrading Strain Pseudomonas sp. Ph6. Environmental Pollution, 240, 359-367. https://doi.org/10.1016/j.envpol.2018.04.125

[31] Sander, L.C. and Wise, S.A. (2011) Polycyclic Aromatic Hydrocarbon Structure Index. NIST Special Publication 922. National Institute of Standards and Technology, United Sates Department of Commerce Technology Administration, Gaithersburg, MD 20899-0001.

[32] Collier, L.S., Nichols, N.N. and Neidle, E.L. (1997) Benk Encodes a Hydrophobic Permease-Like Protein Involved in Benzoate Degradation by Acinetobacter sp. Strain ADP1. Journal of Bacteriology, 179, 5943-5946.

https://doi.org/10.1128/JB.179.18.5943-5946.1997

[33] Clark, T.J., Momany, C. and Neidle, E.L. (2002) The benPK Operon, Proposed to Play a Role in Transport, Is Part of a Regulon for Benzoate Catabolism in Acinetobacter sp. Strain ADP1. Microbiology, 148, 1213-1223.

https://doi.org/10.1099/00221287-148-4-1213

[34] Xu, Y., Wang, S.H., Chao, H.J., Liu, S.J. and Zhou, N.Y. (2012) Biochemical and Molecular Characterization of the Gentisate Transporter Genk in Corynebacterium glutamicum. PLoS ONE, 7, e38701. https://doi.org/10.1371/journal.pone.0038701

[35] Xu, Y., Gao, X., Wang, S.H., Liu, H., Williams, P.A. and Zhou, N.Y. (2012) MhbT Is a Specific Transporter for 3-Hydroxybenzoate Uptake by Gram-Negative Bacteria. Applied and Environmental Microbiology, 78, 6113-6120. https://doi.org/10.1128/AEM.01511-12

[36] Nichols, N.N. and Harwood, C.S. (1997) Pcak, a High-Affinity Permease for the Aromatic Compounds 4-Hydroxybenzoate and Protocatechuate from Pseudomonas putida. Journal of Bacteriology, 179, 5056-5061. https://doi.org/10.1128/JB.179.16.5056-5061.1997

[37] Pernstich, C., Senior, L., Macinnes, K.A., Forsaith, M. and Curnow, P. (2014) Expression, Purification and Reconstitution of the 4-Hydroxybenzoate Transporter PcaK from Acinetobacter sp. ADP1. Protein Expression and Purification, 101, 68-75. https://doi.org/10.1016/j.pep.2014.05.011

[38] Chang, H.K. and Zylstra, G.J. (1999) Characterization of the Phthalate Permease OphD from Burkholderia cepacia ATCC 17616. Journal of Bacteriology, 181, 6197-6199. https://doi.org/10.1128/JB.181.19.6197-6199.1999

[39] Chang, H.K., Dennis, J.J. and Zylstra, G.J. (2009) Involvement of Two Transport Systems and a Specific Porin in the Uptake of Phthalate by Burkholderia Spp. Journal of Bacteriology, 191, 4671-4673. https://doi.org/10.1128/JB.00377-09 
[40] Postma, P.W., Lengeler, J.W. and Jacobson, G.R. (1993) Phosphoenolpyruvate: Carbohydrate Phosphotransferase Systems of Bacteria. Microbiology and Molecular Biology Reviews, 57, 543-594. https://doi.org/10.1128/MMBR.57.3.543-594.1993

[41] Deutscher, J., Francke, C. and Postma, P.W. (2006) How Phosphotransferase System-Related Protein Phosphorylation Regulates Carbohydrate Metabolism in Bacteria. Microbiology and Molecular Biology Reviews, 70, 939-1031. https://doi.org/10.1128/MMBR.00024-06

[42] Kundig, W., Ghosh, S. and Roseman, S. (1964) Phosphate Bound to Histidine in a Protein as an Intermediate in a Novel Phospho-Transferase System. Proceedings of the National Academy of Sciences of the United States of America, 52, 1067-1074. https://doi.org/10.1073/pnas.52.4.1067

[43] Saier Jr., M.H., Hvorup, R.N. and Barabote, R.D. (2005) Evolution of the Bacterial Phosphotransferase System: From Carriers and Enzymes to Group Translocators. Biochemical Society Transactions, 33, 220-224. https://doi.org/10.1042/BST0330220

[44] Zhang, Z.G., Aboulwafa, M., Smith, M.H. and Saier Jr., M.H. (2003) The Ascorbate Transporter of Escherichia coli. Journal of Bacteriology, 185, 2243-2250. https://doi.org/10.1128/JB.185.7.2243-2250.2003

[45] Hvorup, R., Chang, A.B. and Saier Jr., M.H. (2003) Bioinformatic Analyses of the Bacterial L-Ascorbate Phosphotransferase System Permease Family. Journal of Molecular Microbiology and Biotechnology, 6, 191-205. https://doi.org/10.1159/000077250

[46] Nobelmann, B. and Lengeler, J.W. (1996) Molecular Analysis of the Gat Genes from Escherichia coli and of Their Roles in Galactitol Transport and Metabolism. Journal of Bacteriology, 178, 6790-6795. https://doi.org/10.1128/JB.178.23.6790-6795.1996

[47] Wichelecki, D.J., Vetting, M.W., Chou, L., Al-Obaidi, N., Bouvier, J.T., Almo, S.C. and Gerlt, J.A. (2015) ATP-Binding Cassette (ABC) Transport System Solute-Binding Protein-Guided Identification of Novel D-Altritol and Galactitol Catabolic Pathways in Agrobacterium tumefaciens C58. Journal of Biological Chemistry, 290, 28963-28976. https://doi.org/10.1074/jbc.M115.686857

[48] Zúñiga, M., Comas, I., Linaje, R., Monedero, V., Yebra, M.J., Esteban, C.D., Deutscher, J., Pérez-Martínez, G. and González-Candelas, F. (2005) Horizontal Gene Transfer in the Molecular Evolution of Mannose PTS Transporters. Molecular Biology and Evolution, 22, 1673-1685. https://doi.org/10.1093/molbev/msi163

[49] Kinch, L.N., Cheek, S. and Grishin, N.V. (2005) EDD, a Novel Phosphotransferase Domain Common to Mannose Transporter EIIA, Dihydroxyacetone Kinase, and Degv. Protein Science, 14, 360-367. https://doi.org/10.1110/ps.041114805

[50] Milo, R., Jorgensen, P., Moran, U., Weber, G. and Springer, M. (2010) Bionumbers-The Database of Key Numbers in Molecular and Cell Biology. Nucleic Acids Research, 38, D750-D753. https://doi.org/10.1093/nar/gkp889

[51] Huang, L.Y., Catterall, W.A. and Ehrenstein, G. (1978) Selectivity of Cations and Non Electrolytes for Acetylcholine-Activated Channels in Cultured Muscle Cells. Journal of General Physiology, 71, 397-410. https://doi.org/10.1085/igp.71.4.397

[52] Yan, S. and Wu, G. (2017) Reorganization of Gene Network for Degradation of Polycyclic Aromatic Hydrocarbons (PAHs) in Pseudomonas aeruginosa PAO1 under Several Conditions. Journal Applied Genetics, 58, 545-563. https://doi.org/10.1007/s13353-017-0402-9

[53] Fetzner, S. (2012) Ring-Cleaving Dioxygenases with a Cupin Fold. Applied and En- 
vironmental Microbiology, 78, 2505-2514. https://doi.org/10.1128/AEM.07651-11

[54] Willumsen, P.A. and Karlson, U. (1998) Effect of Calcium on the Surfactant tolerance of a Fluoranthene Degrading Bacterium. Biodegradation, 9, 369-379. https://doi.org/10.1023/A:1008357904624

[55] Rojo, F. (2010) Carbon Catabolite Repression in Pseudomonas: Optimizing Metabolic Versatility and Interactions with the Environment. FEMS Microbiology Reviews, 34, 658-684. https://doi.org/10.1111/j.1574-6976.2010.00218.x

[56] Saier Jr., M.H. (2018) The Benzoate: H Symporter (Bene) Family. Transporter Classification Database. http://www.tcdb.org/

[57] Law, C.J., Maloney, P.C. and Wang, D.N. (2008) Ins and Outs of Major Facilitator Superfamily Antiporters. Annual Review of Microbiology, 62, 289-305. https://doi.org/10.1146/annurev.micro.61.080706.093329

[58] Saier Jr., M.H., Beatty, J.T., Goffeau, A., Harley, K.T., Heijne, W.H., Huang, S.C., Jack, D.L., Jähn, P.S., Lew, K., Liu, J., Pao, S.S., Paulsen, I.T., Tseng, T.T. and Virk, P.S. (1999) The Major Facilitator Superfamily. Journal of Molecular Microbiology and Biotechnology, 1, 257-279.

[59] Henderson, P.J. and Maiden, M.C. (1990) Homologous Sugar Transport Proteins in Escherichia coli and Their Relatives in Both Prokaryotes and Eukaryotes. Philosophical Transactions of the Royal Society of London. Series B, Biological Sciences, 326, 391-410. https://doi.org/10.1098/rstb.1990.0020

[60] Dutta, D. and Fliegel, L. (2018) Structure and Function of Yeast and Fungal $\mathrm{Na}^{+} / \mathrm{H}^{+}$ Antiporters. IUBMB Life, 70, 23-31. https://doi.org/10.1002/iub.1701

[61] Paulsen, I.T., Brown, M.H. and Skurray, R.A. (1996) Proton-Dependent Multidrug Efflux Systems. Microbiology Review, 60, 575-608. https://doi.org/10.1128/MMBR.60.4.575-608.1996

[62] Pao, S.S., Paulsen, I.T. and Saier Jr., M.H. (1998) Major Facilitator Superfamily. Microbiology and Molecular Biology Reviews, 62, 1-34. https://doi.org/10.1128/MMBR.62.1.1-34.1998

[63] Wolfersberger, M.G. (1994) Uniporters, Symporters and Antiporters. Journal of Experimental Biology, 196, 5-6.

[64] Williams, P.A. and Shaw, L.E. (1997) mucK, a Gene in Acinetobacter calcoaceticus ADP1 (BD413), Encodes the Ability to Grow on Exogenous cis, cis-Muconate as the Sole Carbon Source. Journal of Bacteriology, 179, 5935-5942. https://doi.org/10.1128/JB.179.18.5935-5942.1997

[65] Harwood, C.S. and Parales, R.E. (1996) The $\beta$-Ketoadipate Pathway and the Biology of Self-Identity. Annual Review of Microbiology, 50, 553-590. https://doi.org/10.1146/annurev.micro.50.1.553

[66] Barbe, V., Vallenet, D., Fonknechten, N., Kreimeyer, A., Oztas, S., Labarre, L., Cruveiller, S., Robert, C., Duprat, S., Wincker, P., Ornston, L.N., Weissenbach, J., Marlière, P., Cohen, G.N. and Médigue, C. (2004) Unique Features Revealed by the Genome Sequence of Acinetobacter sp. ADP1, a Versatile and Naturally Transformation Competent Bacterium. Nucleic Acids Research, 32, 5766-5779. https://doi.org/10.1093/nar/gkh910

[67] Cillingová, A., Zeman, I., Tóth, R., Neboháčová, M., Dunčková, I., Hölcová, M., Jakúbková, M., Gérecová, G., Pryszcz, L.P., Tomáška, L., Gabaldón, T., Gácser, A. and Nosek, J. (2017) Eukaryotic Transporters for Hydroxyl Derivatives of Benzoic Acid. Scientific Reports, 7, Article No. 8998. https://doi.org/10.1038/s41598-017-09408-6 
[68] Middelhoven, W.J., Coenen, A., Kraakman, B. and Sollewijn Gelpke, M.D. (1992) Degradation of Some Phenols and Hydroxybenzoates by the Imperfect Ascomycetous Yeasts Candida parapsilosis and Arxula adeninivorans. Evidence for an Operative Gentisate Pathway. Antonie van Leeuwenhoek, 62, 181-187. https://doi.org/10.1007/BF00582578

[69] Middelhoven, W.J. (1993) Catabolism of Benzene Compounds by Ascomycetous and Basidiomycetous Yeasts and Yeastlike Fungi. A Literature Review and an Experimental Approach. Antonie van Leeuwenhoek, 63, 125-144. https://doi.org/10.1007/BF00872388

[70] Holesova, Z., Jakubkova, M., Zavadiakova, I., Zeman, I., Tomaska, L. and Nosek, J. (2011) Gentisate and 3-Oxoadipate Pathways in the Yeast Candida parapsilosis. Identification and Functional Analysis of the Genes Coding for 3-Hydroxybenzoate 6-Hydroxylase and 4-Hydroxybenzoate 1-Hydroxylase. Microbiology, 157, 2152-2163. https://doi.org/10.1099/mic.0.048215-0

[71] Nichols, N.N. and Harwood, C.S. (1997) PcaK, a High-Affinity Permease for the Aromatic Compounds 4-Hydroxybenzoate and Protocatechuate from Pseudomonas putida. Journal of Bacteriology, 179, 5056-5061. https://doi.org/10.1128/jb.179.16.5056-5061.1997

[72] Nomura, Y., Nakagawa, M., Ogawa, N., Harashima, S. and Oshima, Y. (1992) Genes in PHT Plasmid Encoding the Initial Degradation Pathway of Phthalate in Pseudomonas putida. Journal of Fermentation and Bioengineering, 74, 333-344. https://doi.org/10.1016/0922-338X(92)90028-S

[73] Saint, C.P. and Romas, P. (1996) 4-Methylphthalate Catabolism in Burkholderia (Pseudomonas) cepacia Pc701: A Gene Encoding a Phthalate-Specific Permease forms Part of a Novel Gene Cluster. Microbiology, 142, 2407-2418. https://doi.org/10.1099/00221287-142-9-2407

[74] Karimian, M. and Ornston, L.N. (1981) Participation of the $\beta$-Ketoadipate Transport System in Chemotaxis. Journal of General Microbiology, 124, 25-28. https://doi.org/10.1099/00221287-124-1-25

[75] D’Arrigo, I., Cardoso, J.G.R., Rennig, M., Sonnenschein, N., Herrgård, M.J. and Long, K.S. (2019) Analysis of Pseudomonas putida Growth on Non-Trivial Carbon Sources Using Transcriptomics and Genome-Scale Modelling. Environmental Microbiology Reports, 11, 87-97. https://doi.org/10.1111/1758-2229.12704

[76] Whipp, M.J., Camakaris, H. and Pittard, A.J. (1998) Cloning and Analysis of the Shia Gene, Which Encodes the Shikimate Transport System of Escherichia coli K-12. Gene, 209, 185-192. https://doi.org/10.1016/S0378-1119(98)00043-2

[77] Büchel, D.E., Gronenborn, B. and Müller-Hill, B. (1980) Sequence of the Lactose Permease Gene. Nature, 283, 541-545. https://doi.org/10.1038/283541a0

[78] Mcmorrow, I., Chin, D.T., Fiebig, K., Pierce, J.L., Wilson, D.M., Reeve, E.C. and Wilson, T.H. (1988) the Lactose Carrier of Klebsiella pneumoniae M5a1; the Physiology of Transport and the Nucleotide Sequence of the Lacy Gene. Biochimica et Biophysica Acta, 945, 315-323. https://doi.org/10.1016/0005-2736(88)90494-4

[79] Lee, J.I., Okazakim N., Tsuchiya, T. and Wilson, T.H. (1994) Cloning and Sequencing of the Gene for the Lactose Carrier of Citrobacter freundii. Biochemical and Biophysical Research Communications, 203, 1882-1888.

https://doi.org/10.1006/bbrc.1994.2407

[80] Varela, M.F. and Wilson, T.H. (1996) Molecular Biology of the Lactose Carrier of Escherichia coli. Biochimica et Biophysica Acta, 1276, 21-34. https://doi.org/10.1016/0005-2728(96)00030-8 
[81] Abramson, J., Iwata, S. and Kaback, H. R. (2004) Lactose Permease as a Paradigm for Membrane Transport Proteins. Molecular Membrane Biology, 21, 227-236. https://doi.org/10.1080/09687680410001716862

[82] Bockmann, J., Heuel, H. and Lengeler, J.W. (1992) Characterization of a Chromosomally Encoded, Non-PTS Metabolic Pathway for Sucrose Utilization in Escherichia coli EC3132. Molecular Genetics and Genomics, 235, 22-32. https://doi.org/10.1007/BF00286177

[83] Sahin-Tóth, M., Frillingos, S., Lengeler, J.W. and Kaback, H.R. (1995) Active Transport by the Cscbpermease in Escherichia coli K-12. Biochemical and Biophysical Research Communications, 208, 1116-1123. https://doi.org/10.1006/bbrc.1995.1449

[84] Peng, Y., Kumar, S., Hernandez, R.L., Jones, S.E., Cadle, K.M., Smith, K.P. and Varela, M.F. (2009) Evidence for the Transport of Maltose by the Sucrose Permease, CscB, of Escherichia coli. Journal of Membrane Biology, 228, 79-88. https://doi.org/10.1007/s00232-009-9161-9

[85] Okazaki, N., Jue, X.X., Miyake, H., Kuroda, M., Shimamoto, T. and Tsuchiya, T. (1997) A Melibiose Transporter and an Operon Containing Its Gene in Enterobacter cloacae. Journal of Bacteriology, 179, 4443-4445. https://doi.org/10.1128/JB.179.13.4443-4445.1997

[86] Yazyu, H., Shiota-Niiya, S., Shimamoto, T., Kanazawa, H., Futai, M. and Tsuchiya, T. (1984) Nucleotide Sequence of the MelB Gene and Characteristics of Deduced Amino Acid Sequence of the Melibiose Carrier in Escherichia coli. Journal of Biological Chemistry, 259, 4320-4326.

[87] Botfield, M.C., Naguchi, K., Tsuchiya, T. and Wilson, T.H. (1992) Membrane Topology of the Melibiose Carrier of Escherichia coli. Journal of Biological Chemistry, 267, 1818-1822.

[88] Mus-Veteau, I. and Leblanc, G. (1996) Melibiose Permease of Escherichia coli: Structural Organization of Cosubstrate Binding Sites as Deduced from Tryptophan Fluorescence Analyses. Biochemistry, 35, 12053-12060. https://doi.org/10.1021/bi961372g

[89] Ethayathulla, A.S., Yousef, M.S., Amin, A., Leblanc, G., Kaback, H.R. and Guan, L. (2014) Structure-Based Mechanism for $\mathrm{Na}^{+} /$Melibiose Symport by MelB. Nature Communications, 5, Article No. 3009. https://doi.org/10.1038/ncomms4009

[90] Kaback, H.R. (1997) A Molecular Mechanism for Energy Coupling in a Membrane Transport Protein, the Lactose Permease of Escherichia coli. Proceedings of the National Academy of Sciences of the United States of America, 94, 5539-5543. https://doi.org/10.1073/pnas.94.11.5539

[91] Kaback, H.R., Sahin-Tóth, M. and Weinglass, A.B. (2001) The Kamikaze Approach to Membrane Transport. Nature Reviews Molecular Cell Biology, 2, 610-620. https://doi.org/10.1038/35085077

[92] Weinglass, A.B., Sondej, M. and Kaback, H.R. (2002) Manipulating Conformational Equilibria in the Lactose Permease of Escherichia coli. Journal of Molecular Biology, 315, 561-571.

[93] Abramson, J., Smirnova, I., Kasho, V., Verner, G., Kaback, H.R. and Iwata, S. (2003) Structure and Mechanism of the Lactose Permease of Escherichia coli. Science, 301, 610-615. https://doi.org/10.1126/science.1088196

[94] Neidle, E.L., Hartnett, C., Ornston, L.N., Bairoch, A., Rekik, M. and Harayama, S. (1991) Nucleotide Sequences of the Acinetobacter calcoaceticus Benabc Genes for Benzoate 1,2-Dioxygenase Reveal Evolutionary Relationships among Multicompo- 
nent Oxygenases. Journal of Bacteriology, 173, 5385-5395. https://doi.org/10.1128/JB.173.17.5385-5395.1991

[95] Mörtberg, M. and Neujahr, H.Y. (1985) Uptake of Phenol by Trichosporon Cutaneum. Journal of Bacteriology, 161, 615-619.

[96] Mörtberg, M., Spånning, A. and Neujahr, H.Y. (1988) Induction of High-Affinity Phenol Uptake in Glycerol-Grown Trichosporon cutaneum. Journal of Bacteriology, 170, 2383-2384. https://doi.org/10.1128/JB.170.5.2383-2384.1988

[97] Shimizu, M., Kobayashi, Y., Tanaka, H. and Wariishi, H. (2005) Transportation Mechanism for Vanillin Uptake through Fungal Plasma Membrane. Applied Microbiology and Biotechnology, 68, 673-679. https://doi.org/10.1007/s00253-005-1933-2

[98] Gopal, E., Miyauchi, S., Martin, P.M., Ananth, S., Roon, P., Smith, S.B. and Ganapathy, V. (2007) Transport of Nicotinate and Structurally Related Compounds by Human SMCT1 (SLC5A8) and Its Relevance to Drug Transport in the Mammalian Intestinal Tract. Pharmaceutical Research, 24, 575-584. https://doi.org/10.1007/s11095-006-9176-1

[99] Titgemeyer, F., Mason, R.E. and Saier Jr., M.H. (1994) Regulation of the Raffinose Permease of Escherichia coli by the Glucose-Specific Enzyme IIA of the Phosphoenolpyruvate: Sugar Phosphotransferase System. Journal of Bacteriology, 176, 543-546. https://doi.org/10.1128/JB.176.2.543-546.1994

[100] Schmid, K. and Schmitt, R. (1976) Raffinose Metabolism in Escherichia coli K12. Purification and Properties of a New $\alpha$-Galactosidase Specified by a Transmissible Plasmid. European Journal of Biochemistry, 67, 95-104. https://doi.org/10.1111/j.1432-1033.1976.tb10637.x

[101] Aslanidis, C., Schmid, K. and Schmitt, R. (1989) Nucleotide Sequences and Operon Structure of Plasmid-Borne Genes Mediating Uptake and Utilization of Raffinose in Escherichia coli. Journal of Bacteriology, 171, 6753-6763. https://doi.org/10.1128/JB.171.12.6753-6763.1989

[102] Van Camp, B.M., Crow, R.R., Peng, Y. and Varela, M.F. (2007) Amino Acids That Confer Transport of Raffinose and Maltose Sugars in the Raffinose Permease (RafB) of Escherichia coli as Implicated by Spontaneous Mutations at Val-35, Ser-138, Ser-139, Gly-389 and Ile-391. Journal of Membrane Biology, 220, 87-95. https://doi.org/10.1007/s00232-007-9077-1

[103] Misko, T.P., Mitchell, W.J., Meadow, N.D. and Roseman, S. (1987) Sugar Transport by the Bacterial Phosphotransferase System. Reconstitution of Inducer Exclusion in Salmonella Typhimurium Membrane Vesicles. Journal of Biological Chemistry, 262, 16261-16266.

[104] Henderson, P.J.F., Giddens, R.A. and Jones-Mortimer, M.C. (1977) The Transport of Galactose, Glucose and their Molecular Analogues by Escherichia coli K12. Biochemical Journal, 162, 309-320. https://doi.org/10.1042/bj1620309

[105] Mcdonald, T.P., Walmsley, A.R. and Henderson, P.J.F. (1997) Asparagine 394 in Putative Helix 11 of the Galactose- $\mathrm{H}^{+}$Symport Protein (Galp) from Escherichia Coli Is Associated with the internal Binding Site for Cytochalasin B and Sugar. Journal of Biological Chemistry, 272, 15189-15199. https://doi.org/10.1074/jbc.272.24.15189

[106] Mcdonald, T.P. and Henderson, P.J.F. (2001) Cysteine Residues in the D-Galactose- $\mathrm{H}^{+}$ Symport Protein of Escherichia coli: Effects of Mutagenesis on Transport, Reaction with N-Ethylmaleimide and Antibiotic Binding. Biochemical Journal, 353, 709-717. https://doi.org/10.1042/bj3530709

[107] Zheng, H., Taraska, J., Merz, A.J. and Gonen, T. (2010) The Prototypical H+/Galactose 
Symporter Galp Assembles into Functional Trimers. Journal of Molecular Biology, 396, 593-601. https://doi.org/10.1016/j.jmb.2009.12.010

[108] Behera, B.K., Das, A., Sarkar, D.J., Weerathunge, P., Parida, P.K., Das, B.K., Thavamani, P., Ramanathan, R. and Bansal, V. (2018) Polycyclic Aromatic Hydrocarbons (PAHs) in Inland Aquatic Ecosystems: Perils and Remedies through Biosensors and Bioremediation. Environmental Pollution, 241, 212-233.

https://doi.org/10.1016/j.envpol.2018.05.016

[109] Rizzuto, R., Pinton, P., Brini, M., Chiesa, A., Filippin, L. and Pozzan, T. (1999) Mitochondria as Biosensors of Calcium Microdomains. Cell Calcium, 26, 193-199. https://doi.org/10.1054/ceca.1999.0076

[110] Li, X., Kaattari, S.L., Vogelbein, M.A., Vadas, G.G. and Unger, M.A. (2016) A Highly Sensitive Monoclonal Antibody Based Biosensor for Quantifying 3-5 Ring Polycyclic Aromatic Hydrocarbons (PAHs) in Aqueous Environmental Samples. Sensing and Bio-Sensing Research, 7, 115-120.

https://doi.org/10.1016/j.sbsr.2016.02.003

[111] Denome, S.A., Stanley, D.C., Olson, E.S. and Young, K.D. (1993) Metabolism of Dibenzothiophene and Naphthalene in Pseudomonas Strains: Complete DNA Sequence of an Upper Naphthalene Catabolic Pathway. Journal of Bacteriology, 175, 6890-6901. https://doi.org/10.1128/JB.175.21.6890-6901.1993

[112] Baboshin, M., Akimov, V., Baskunov, B., Born, T.L., Khan, S.U. and Golovleva, L. (2008) Conversion of Polycyclic Aromatic Hydrocarbons by Sphingomonas sp. VKM B-2434. Biodegradation, 19, 567-576. https://doi.org/10.1007/s10532-007-9162-2

[113] Wattiau, P., Bastiaens, L., Van Herwijnen, R., Daal, L., Parsons, J.R., Renard, M.E., Springael, D. and Cornelis, G.R. (2001) Fluorene Degradation by Sphingomonas sp. LB126 Proceeds through Protocatechuic Acid: A Genetic Analysis. Research in Microbiology, 152, 861-872. https://doi.org/10.1016/S0923-2508(01)01269-4

[114] Jouanneau, Y., Meyer, C., Jakoncic, J., Stojanoff, V. and Gaillard, J. (2006) Characterization of a Naphthalene Dioxygenase Endowed with an Exceptionally Broad Substrate Specificity toward Polycyclic Aromatic Hydrocarbons. Biochemistry, 45, 12380-12391. https://doi.org/10.1021/bi0611311

[115] Choudhary, A., Modak, A., Apte, S.K. and Phale, P.S. (2017) Transcriptional Modulation of Transport- and Metabolism-Associated Gene Clusters Leading to Utilization of Benzoate in Preference to Glucose in Pseudomonas putida CSV86. Applied and Environmental Microbiology, 83, e01280-17.

https://doi.org/10.1128/AEM.01280-17 